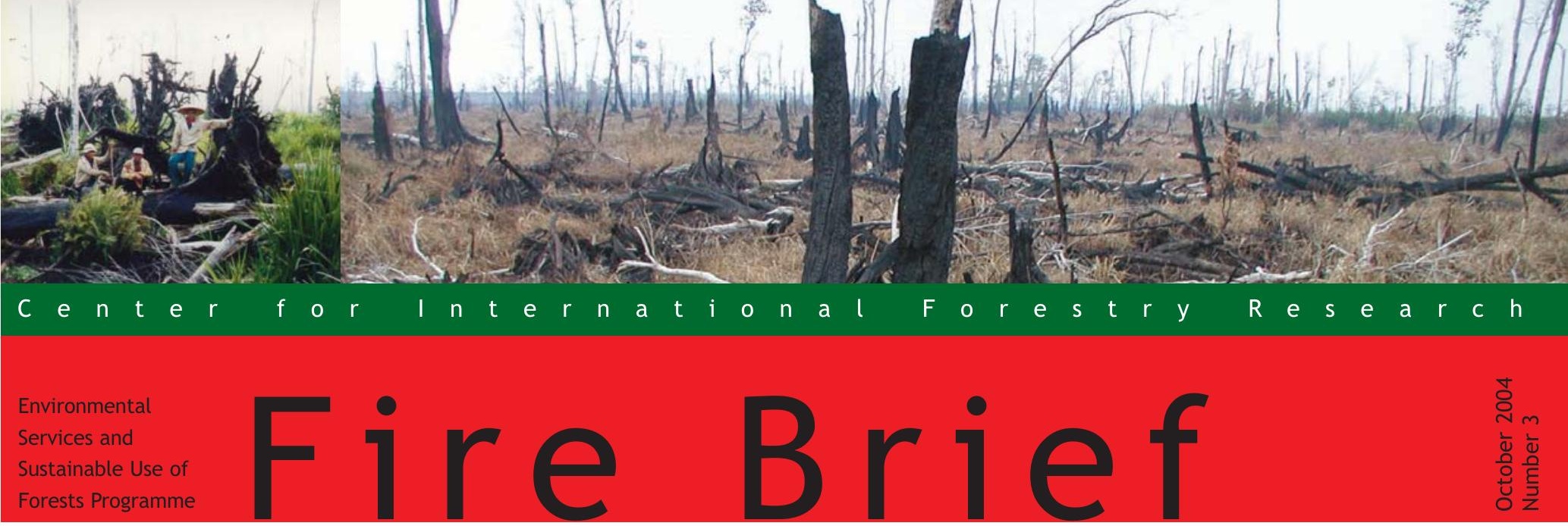

\title{
Fire, livelihoods and environmental degradation in the wetlands of Indonesia: A vicious cycle
}

By Unna Chokkalingam, CIFOR (u.chokkalingam@cgiar.org)

and Suyanto, ICRAF (suyanto@cgiar.org)

Indonesia contains a large area of peat and connected freshwater wetlands, approximately 19 million hectares or 10 percent of the land area'. Peatlands make up $89 \%$ of the 19 million hectares. Most of these wetlands are located on three islands, West Papua, Sumatra, and Kalimantan. These tropical wetlands are naturally covered by closed forest and often contain valuable timber species - however, their commercial extraction appears unsustainable. They play a critical role in carbon storage, biodiversity conservation and hydrological regulation. They are also a major breeding ground of fish for both domestic and export markets. Many people rely on these wetlands for livelihood support, often in the form of fishing, logging and agriculture.

\section{The fire problem in the wetlands}

Indonesia's wetlands have suffered extensive fire damage in recent El Niño years. In the 1997/98 El Niño event, forest fires on dried-out wetlands accounted for 2.1 million ha or 18 percent of the total area burnt in Indonesia ${ }^{2}$. As would be expected, much of the burning occurred in logged or drained wetlands, such as those in southern Sumatra. But even intact peat forests such as in the Middle Mahakam Area, East Kalimantan and Berbak National Park, Jambi suffered due to increased human activities (such as turtle

Fire in the Gelam forest, Lampung. hunting and logging) within the forests.

Fires are also common in non El Niño years but are smaller in scale and restricted to accessible areas along rivers, streams and lakes ${ }^{3,4}$. Deforested and drained peatlands are, however, becoming major annual fire flashpoints, such as in Central and West Kalimantan and, more recently, in Riau.

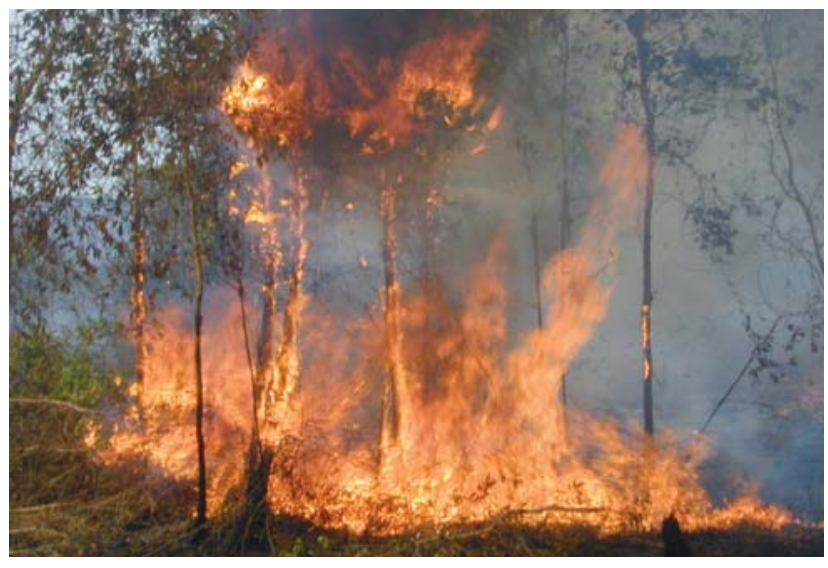

Compared with dryland fires, wetland fires tend to have larger negative environmental impacts of concern on a regional to global scale. They are a major source of both the annual smoke haze blanketing Southeast Asia and the greenhouse gas emissions contributing to global warming. In the $1997 / 98 \mathrm{El}$ Niño event, Indonesian wetland fires accounted for 60 percent of the regional haze ${ }^{5}$ and emitted 0.81-2.57 Gt of Carbon ${ }^{6}$, making Indonesia one of the largest air polluters in the world. In Kalimantan and Sumatra, recurrent fires and associated disturbances in wetlands have led to widespread deforestation, forest degradation and biodiversity loss. In East Kalimantan, repeatedly burnt degraded forests are ultimately transformed into open floodplains and shallow lakes as the peat collapses with vegetation removal or is lost with burning. 
Turtle hunting in East Kalimantan

In the 1997-98 El Niño period, around 72-85 percent of the Middle Mahakam Peatlands was burnt. Much of it was mature forest that had not burnt before. These extensive fires are attributed to the extremely dry conditions and the use of fire while hunting turtles or collecting tree bark. Fishing is the pre-dominant livelihood source in the area but river levels dropped in the El Niño period, making navigation and transport of fish difficult. New high-value markets emerged for turtle meat and for tree bark used as an ingredient in commercial mosquito coils. The local government permitted quota-free collection of these items in response to the drought crisis. Thousands of people switched to these alternative activities and entered remote interior peat forests that were scarcely visited before. Fire was used to improve access into the forest, for camping, and to concentrate the turtles in damp areas and catch them easily by burning off the surrounding vegetation. While these activities helped local people survive a difficult drought year as intended, they resulted in widespread fires that damaged the entire peat ecosystem and contributed to the smoke and haze problem.

\section{A vicious cycle of degradation and long-term fire problem}

Once degraded, wetland landscapes are prone to recurring fires because they are more easily accessed and more flammable. People are quick to use the newly opened-up areas and the zone of degradation gradually expands from the rivers into interior peatlands. Drained peatlands can become a major annual fire problem. It is very difficult to convert wetlands to sustainable alternative land use.

Recurrent fires reduce the potential for regrowth and recovery. In southern Sumatra, communities report negative impacts of repeated fires on hydrology, soils, fish resources and agricultural yields ${ }^{3}$. Resource degradation following logging and fires has forced down household incomes and livelihood options. The impacts extend beyond local areas as workers migrate into neighbouring forests to extract resources. On the other hand, local communities in East Kalimantan that depend on peatland fish resources perceive positive benefits from fire use and landscape transformation following the widespread fires of the recent El Niño events ${ }^{4}$. Clearly more research is needed into the longer-term impacts of such peatland transformation on hydrology, fish populations and thus livelihoods.

\section{Key recommendations to solve the wetland fire problem}

Livelihood improvement and sustainable management:

1. Develop an El Niño response program for wetlands aimed at reducing fire use by communities and providing alternative sustainable livelihood options at these critical times, preferably outside these vulnerable areas.

2. On already degraded or still forested wetlands under severe livelihood pressures, develop a multi-faceted policy to control fires, arrest environmental degradation and halt the spread of unsustainable practices, while supporting livelihoods.

a. Examine the technical and socio-economic feasibility of practising controlled burning for local wetland use in the accessible areas along waterways, particularly in long drought years, so that fires are contained.

b. Rehabilitate, conserve and restrict activities within much of the wetlands beyond the broad strips along the rivers and lakes to prevent further large-scale fires, haze, carbon emissions, and environmental degradation.

c. Develop viable livelihood options, such as small-scale plantations, agroforestry, and fish farming on suitable sites that will

\section{Sonor in southern Sumatra ${ }^{3}$}

Widespread fires in the wetlands of South Sumatra and Lampung in the last El Niño periods of 1991, 1994 and 1997/98 were partly due to sonor, a traditional system of wetland rice cultivation. Sonor is practised by using fire during prolonged droughts of five to six months. As the wetlands dry out, surface vegetation is burned and rice seeds are broadcast on the ash-enriched soil. As water levels rise, the rice grows and is eventually harvested using boats. Sonor produces bumper crops and requires little expense, maintenance and labour. It is a simple and economical way of overcoming the lack of suitable permanent rice cultivation sites in the wetlands, the limited alternative livelihood options, and the failure of upland crops during long droughts. The practice of sonor has expanded across southern Sumatra following the transformation of mature high forest landscapes into flammable Gelam (Melaleuca cajuputi) forests and thickets. It became more common as the incidence of droughts increased, new areas became accessible through canals, and new migrants also adopted the practice. 
improve local economic conditions while reducing fire and degradation problems.

d. As part of rural development projects, negotiate arrangements whereby communities agree to control their burning and to protect and restore larger wetland areas beyond the annually burnt strips. Provide incentives, raise awareness, and set up local institutions and regulations to support and implement such measures.

3. On established transmigration sites, support community interest in shifting from annual to estate crops or agroforestry in partnership with companies. This could help improve livelihoods and avoid annual burning.

Large-scale development:

4. For currently remote, sparsely-inhabited forested wetlands of Indonesia, reconsider development policies to avoid the vicious cycle of fire and environmental degradation. Avoid large-scale developments (such as commercial logging, transmigration and plantation development) that deforest or drain the peatlands, improve access and increase the population pressures in these marginal areas.

5. Review the appropriateness of existing wetland use allocation for logging and plantation development versus conservation or community use in different regions including all stakeholders.

\section{References}

1. RePPProT. 1990. The Land Resources of Indonesia: A National Overview, Land Resources Department, Natural Resources
Institute, Overseas Development Administration, London, UK and Direktorat Bina Program, Direktorat Jenderal, Penyiapan Pemukiman, Departemen Transmigrasi, Jakarta, Indonesia.

2. Tacconi, L. 2003. Fires in Indonesia: Causes, costs and policy implications. CIFOR occasional paper No. 38. CIFOR, Bogor, Indonesia.

3. Chokkalingam, U., Suyanto, Permana, R. P., Kurniawan, I., Mannes, J., Darmawan, A., Khususyiah, N. and Susanto, R. H. Forthcoming. Community fire use, resource change and livelihood impacts: The downward spiral in the wetlands of southern Sumatra. Mitigation and Adaptation Strategies for Global Change.

4. Chokkalingam, U., Kurniawan, I. and Ruchiyat, Y. Manuscript. Fire, livelihoods and environmental degradation in the Middle Mahakam Peatlands. CIFOR, Bogor, Indonesia.

5. ADB (Asian Development Bank)/BAPPENAS (National Development Planning Agency). 1999. Causes, Extent, Impact and Costs of 1997/98 Fires and Drought. Final Report, Annex 1 and 2. Planning for Fire Prevention and Drought Management Project, Asian Development Bank, TA 2999-INO Fortech, Pusat Pengembangan Agribisnis, Margules Pöyry, Jakarta, Indonesia.

6. Page, S. E., Siegert, F., Rieley, J. O., Boehm, HD. V., Jaya A. and Limin S. 2002. The amount of carbon release from peat and forest fires in Indonesia during 1997. Nature 420:61-65.

7. Chokkalingam, U. and Suyanto. 2004. Summary of workshop results. Pages 20-34 in Kebakaran di Lahan Rawa/Gambut di Sumatera: Masalah dan Solusi. CIFOR, Bogor, Indonesia.
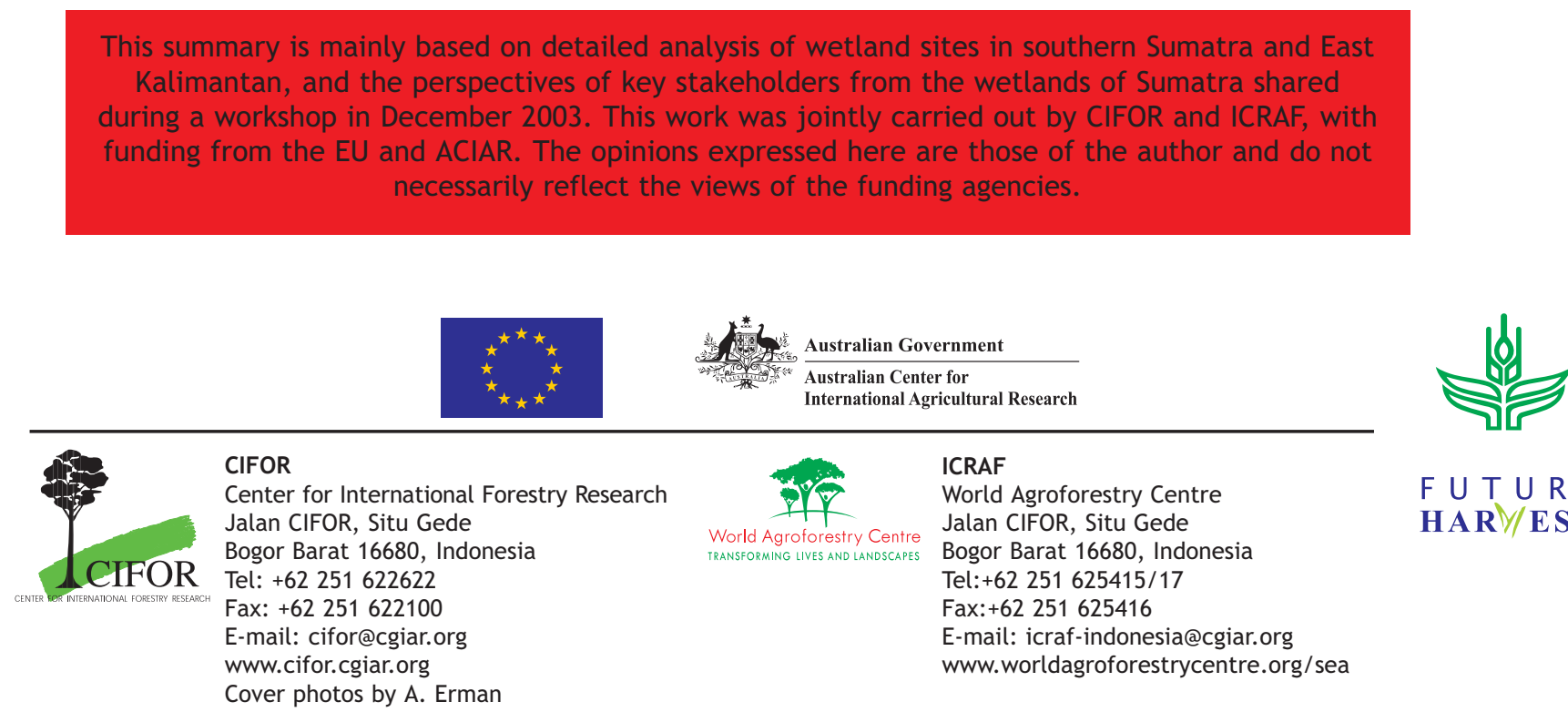

F U T U R E

HAR R//EST

The brief is also available in Bahasa Indonesia 